Regina ZBANYSZEK

Physiology

\title{
THE EFFECT OF SULPHATES AND PHOSPHATES (INDUSTRIAL WASTES) ON THE MUCOPOLYSACCHARIDES CONTENT OF THE GILLS OF THE EEL ANGUILLA ANGUILLA (L.)
}

WPŁYW SIARCZANÓW I FOSFORANÓW (ŚCIEKÓW PRZEMYSŁOWYCH) NA ZAWARTOŚĆ MUKOPOLISACHARYDÓW W SKRZELACH WĘGORZA ANGUILLA ANGUILLA (L.)

Institute of Ichthyology

Department of Fish Physiology

\begin{abstract}
Industrial wastes, the main components of which were sulphates and phosphates, induced a decrease in the intensity of staining reactions for mucopolysaccharides (MPS) in the gills of eels. The changes in the MPS content were positively correlated with the vital changes in fishes kept in waste water with an increased sulphate content at a raised $\mathrm{pH}$ value.
\end{abstract}

An increase in the quantity of ionic substances in industrial wastes carried off to waters leads through the physico-chemical changes of cell membranes to those in the intensity of physiological processes of aquatic organisms. These changes have an inhibitory effect on biochemical reactions at different stages of metabolism, bringing about, above all, disturbances in the respiratory processes and ion exchange. In fishes the ion exchange between the external and the internal environment takes place of the mucus secreted by the gill epithelium are mucopolysaccharides, which especially exposed to the unfavourable action of water environment, as the pollution of this last increases.

As will be seen from numerous studies (Halsband, 1972; Heinonen and Falsk, 1971; Kühn and Koecke, 1956; Skidmore and Tovell, 1972), both organic and inorganic ions penetrate through the gill epithelium and cause pathological changes in the gills, such as 
the occurrence of necrosis, haemorrhage in gill filaments, increased secretion of mucus, etc. (Fujiya, 1965).

The way of ions from the water environment to the gills leads through the layer of mucus that covers the gill epithelium. The main conștituents the mucus secreted by the gill epithelium are mucopolysaccharides, which play an important role in many physiological and pathological processes (Brimacombe, 1964).

The decision to investigate the influence of the industrial wastes carried off by the Chemical Works to the Szczecin Firth on the course of changes in the mucopoly. saccharides content of the eel gills was prompted by the progressive process of pollution of waters with industrial wastes and the continuous decrease in the catches of eel in this region during the last years. The effect of sulphates and phosphates, the main components of the waste water, has been investigated in the present study.

The question arises at the same time whether the changes in the mucopolysaccharides content are positively correlated with the course of vital changes in fishes occurring in the waste water under study.

\section{MATERIAL AND METHOD}

The present study was carried out on 176 eels Anguilla anguilla (L.), $60-71 \mathrm{~cm}$ in length and 350-680 g in weight, caught from June to November 1972 and kept under definite experimental conditions. Gills were used as material for histochemical assays. Biological examination

Fishes were studied in two parallel groups, a control and an experimental. In either of them the temperature, $\mathrm{pH}$ value and oxygen content of water were measured. The control group consisted of eels kept in aerated tap water. The experimental groups was studied in two environments: waste water drained off from the Chemical Works, conventionally referred to further in this paper as "natural waste water", and tap water with an addition of sulphates and phosphates, which for distinction will be termed "artificial waste water".

The experimental group of fishes was studied in the "natural waste water" both in the summer period (VI-VIII) and in the autumn (X-XI), whereas in the "artificial waste water" only in the autumn.

The "natural waste water" came exclusively from the Chemical Works and was taken at an inspection point, in the place where the Jasienicki Canal opens into the Roztoka Odrzańska. Each time samples of waste water were examined for the content of sulphates and phosphates, the temperature and $\mathrm{pH}$ of water being also noted. In order to estimate the influence of sulphates and phosphates on the organism of fishes "artificial waste water" was prepared. This aimed at the elimination of the action of additional components contained in the "natural waste water". As the amount of phosphates in the industrial waste water kept within invariable limits, the amount of sulphates in the "artificial waste water". was successively increased to demonstrate unequivocal changes taking place under their influence in the dynamics of mucopolysaccharide metabolism.

The "artificial waste water" was prepared from ready products delivered by the Chemical Works by adding $20-100 \mathrm{mg} / \mathrm{l}$ ammonium phosphate and $0.5-4.0 \mathrm{ml}$ sulphuric 
acid to tap water in aquaria. The whole was alkalized with milk of lime for phosphates to precipitate, just as it is done at the Chemical Works. The precipitate was separated and in the remaining solution fishes were kept in aquaria, which differed in sulphate content and $\mathrm{pH}$ value. The waste water was chemically analysed for sulphates and phosphates twice, before and after the experiment.

\section{Histochemical assays}

A fish, removed from water, was killed by decapitation, its gills were excised and placed directly in fixatives, i.e. buffered $10 \%$ formalin, and Zenker's, Baker's and Carnoy's fluids. The material was embedded in paraffin blocks and sectioned at 5-10 $\mu \mathrm{m}$.

The following methods were used to demonstrate mucopolysaccharides, especially acid ones: PAS according to McManus with Schiff's reagent (McManus, 1946), PAS with Alcian blue (Münch and Ernst, 1964) Astra blue (Pearse, 1968), Alcian blue (Mowry, 1956), and the method for metachromasia with Toluidine blue (Krygier and Kasprzak, 1961). In order to test the specificity of staining by the PAS method, it was employed after acetylation.

\section{RESULTS AND THEIR DISCUSSION}

\section{Biological observation of fishes}

The results of biological observations of fishes belonging to the experimental group kept in the "natural waste water" for 24-72 hours in the summer period and 2-6 hours in the autumn, and in the "artificial waste water", in which they stayed in aquaria with different proportions of sulphates at various $\mathrm{pH}$ for $2-72$ hours, are given in Tables 1 and 2 .

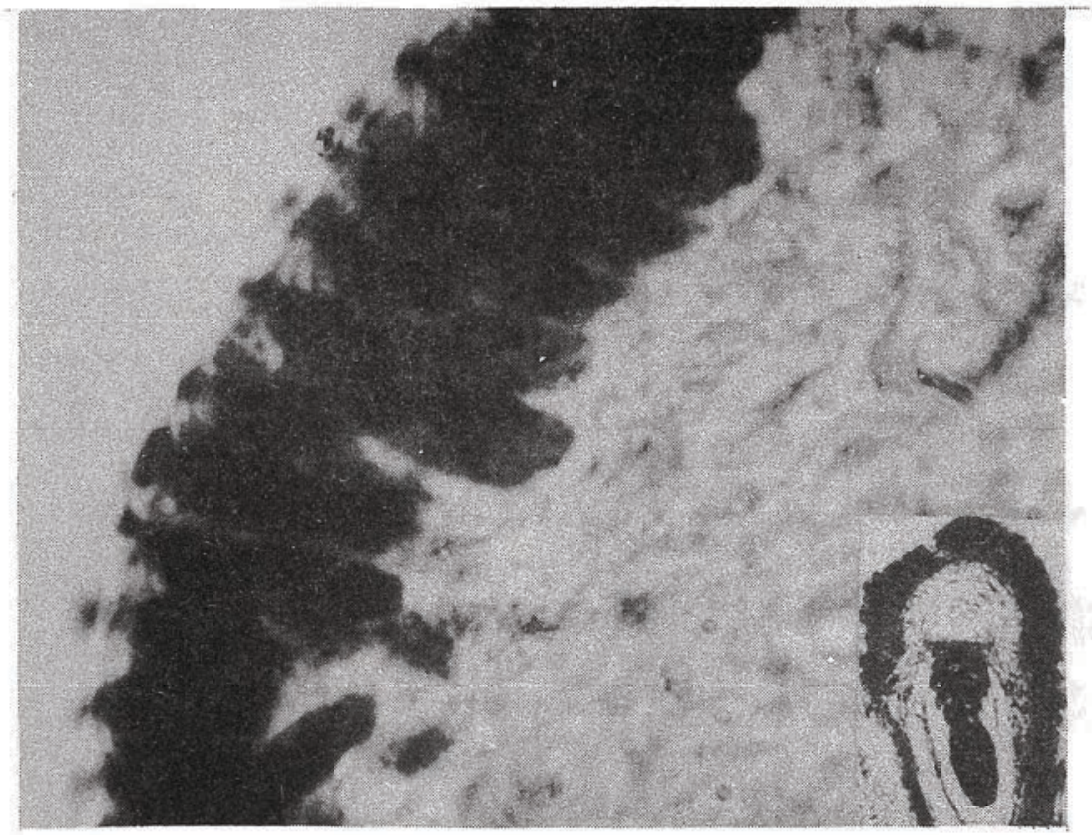

Phot. 1. Control section. Cross-section through a gill filament of the eel. Positive reaction for mucopolysaccharides (MPS) in mucous cells. PAS. x 1200. 
Table 1

Biological investigation of eels in "natural waste water"

\begin{tabular}{|c|c|c|c|c|c|c|c|c|c|}
\hline \multicolumn{10}{|c|}{ Summer } \\
\hline $\begin{array}{c}\text { Aquarium } \\
\text { No. }\end{array}$ & $\begin{array}{c}\text { Sulphates } \\
\mathrm{SO}_{4} \\
\mathrm{~g} / 1\end{array}$ & $\begin{array}{l}\text { Phosp } \\
\mathrm{PO}_{4}\end{array}$ & $\begin{array}{l}\text { hates } \\
\mathbf{P}_{2} \mathbf{O}_{5}\end{array}$ & $\mathrm{pH}$ & $\begin{array}{l}\text { Temp. } \\
\text { in }{ }^{\circ} \mathrm{C}\end{array}$ & $\begin{array}{c}\mathrm{O}_{2} \text { content } \\
\text { in } \mathrm{mg} / \mathrm{l}\end{array}$ & \begin{tabular}{|c|}
\multicolumn{1}{|c|}{ Time of } \\
stay of \\
fishes in \\
waste water, \\
in hours
\end{tabular} & & Symptoms \\
\hline 1 & 0.25 & 0.03 & 0.02 & 7.7 & 20 & 7.5 & 48 & & - no deviation from standard \\
\hline 2 & 0.28 & 0.02 & 0.02 & 7.7 & 20 & 7.0 & 24 & & - no deviation from standard \\
\hline 3 & 0.32 & 0.03 & 0.02 & 8.0 & 21 & 7.0 & 72 & & $\begin{array}{l}\text { - abatement of locomotory } \\
\text { movements }\end{array}$ \\
\hline \multicolumn{10}{|c|}{ Autumn } \\
\hline 4 & 0.77 & 0.02 & 0.01 & 9.7 & 14 & 7.0 & 6 & $\begin{array}{l}\text { after } 1 \text { hour } \\
\text { after } 4 \text { hours } \\
\text { after } 5 \text { hours } \\
\text { after } 6 \text { hours }\end{array}$ & $\begin{array}{l}\text { - strong excitation, attempts at } \\
\text { jumping out of aquarium (sym } \\
\text { ptoms of dyspnoea) } \\
\text { - strong tonic convulsions of } \\
\text { skeletal muscles, bend of } \\
\text { trunk, rigidity of back } \\
\text { - disturbances in co-ordination } \\
\text { of movements, loss of body } \\
\text { balance, "suspended } \\
\text { swimming" } \\
\text { - death }\end{array}$ \\
\hline 5 & 1.0 & 0.01 & 0.01 & 9.7 & 13 & 7.5 & 3 & $\begin{array}{l}\text { after } 30 \text { min } \\
\text { after } 1 \text { hour } \\
\text { after } 2 \text { hour } \\
\text { after } 3 \text { hours }\end{array}$ & $\begin{array}{l}\text { - strong excitation, attempts } \\
\text { at jumping out of aquarium } \\
\text { - strong tonic convulsions } \\
\text { of skeletal muscles, strong } \\
\text { bend of body } \\
\text { - disturbances in motor co-ordi- } \\
\text { nation, loss of body balance, } \\
\text { "suspended swimming" } \\
\text { - deth }\end{array}$ \\
\hline
\end{tabular}


2. Histochemical examination of the eel gills in the control group

In assays for mucopolysaccharides (MPS) the PAS technique gave a positive reaction in the layer of epithelial cells. The mucus cells, among the epithelial ones, were very intensely stained amaranth-red (Phot. 1). The cartilaginous tissue of the gill filaments was also intensely stained pink and the basement membrane assumed a pale pink colour.

3. Examination of the eel gills in the experimental group exposed to the action of the „matural waste water":

\section{Summer}

Fishes kept in waste water for 24 hours (Table 1)

With the PAS method the epithelial layer of the eel gills stained pale pink and so did the cartilaginous tissue. Staining for acid mucopolysaccharides (AMPS) gave a weaker reaction in the mucous cells and cartilage.

Fishes kept in waste water for 48 hours

No positive reaction was found in the basement membrane after using the PAS technique. The cartilaginous tissue of the gill filaments stained pale pink. The mucous cells also showed a weaker reaction for MPS.

Fishes kept in waste water for 72 hours

With the use of the PAS method and staining methods for AMPS, a conspicuous decrease in the intensity of staining reaction was observed both in the cartilaginous tissue

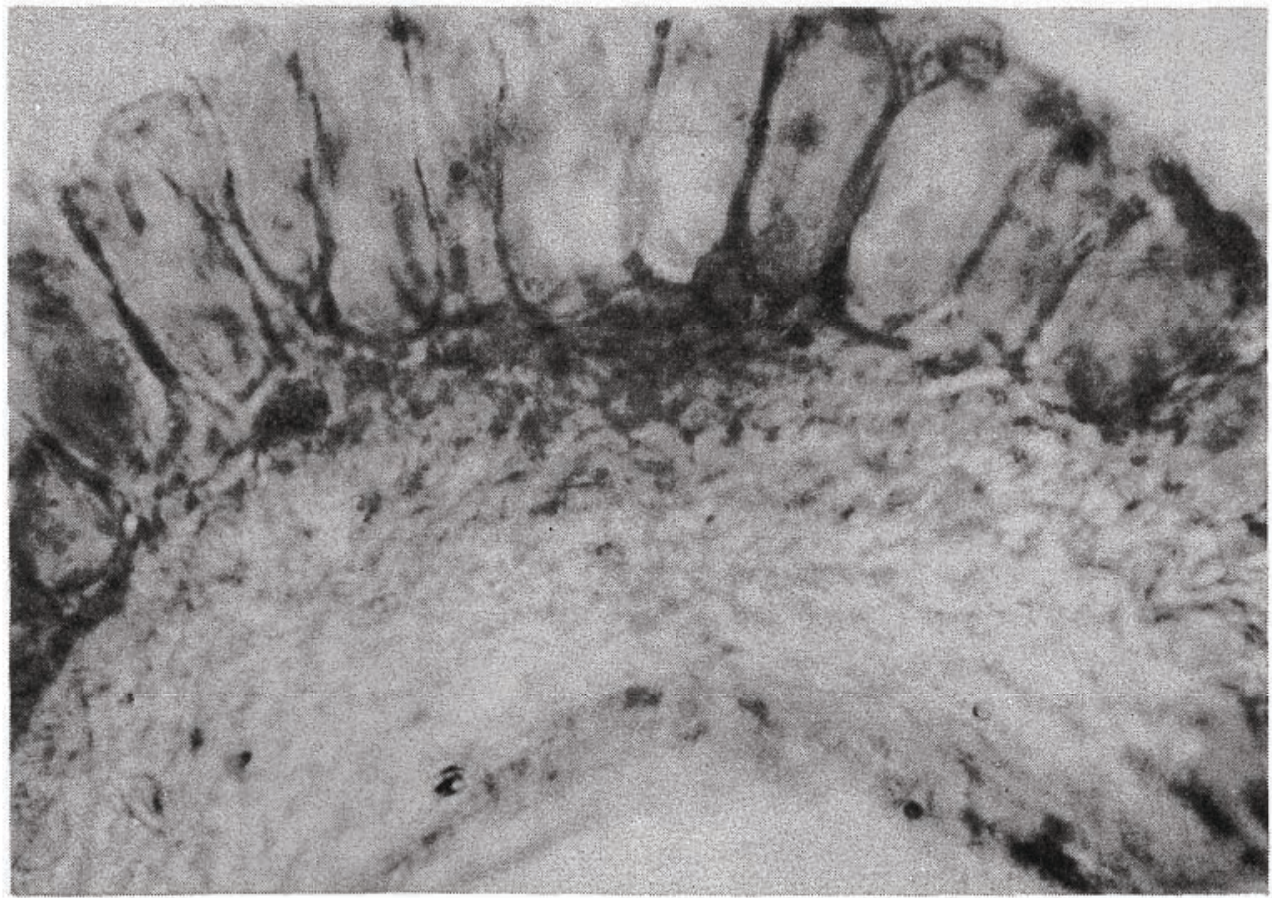

Phot. 2. Cross-section through a gill filament of the eel. Slight positive reaction for mucopolysact charides in mucous cells of gill epithelium. Time of stay in "natural waste water" - 72 hours. Sulphate content $-0.32 \mathrm{~g} \mathrm{SO}_{4} / 1$; phosphate content $-0.03 \mathrm{~g} \mathrm{PO}_{4} / 1$. pH 8.0. PAS. x 1200. 
and in the mucous cells, there being no staining in the basement membrane. Some of the mucous cells remained unstained (Phot. 2).

It may be stated that in the summer period the intensity of PAS positive reactions decreased in fishes staying in the "natural waste water", in which the sulphate content was $0.25-0.32 \mathrm{~g} \mathrm{SO}_{4} / 1$ at $\mathrm{pH} 7.7-8.0$, as the time of their stay in this environment was prolonged (24-72 hours). There was also a fall in the intensity of reactions in sections stained with Alcian blue and Astra blue.

\section{Autumn}

In the autumn period, when the quantity of sulphates in the waste water increased to $0.77 \mathrm{~g} \mathrm{SO}_{4} / 1$ and $\mathrm{pH}$ to 9.7 , enhanced secretion of mucous into the water environment (Phot. 3) was noted in the gills of fishes kept in it for a short time (1 hour). After secreting mucus, some mucous cells remained unstained (Phot. 4). A decrease in the intensity of the PAS positive reaction occured in the layer of mucous cells in the top portions of the gill filaments as early as 2 hours after the fishes were placed in the waste waterr. Some cells were hardly stained (Phot. 5). A further decrease in the intensity of reaction for MPS was observed after a longer stay of fishes in the waste water (6 hours). Astra blue stained only the ground substance of the cartilage pale blue. There was a slight PAS positive

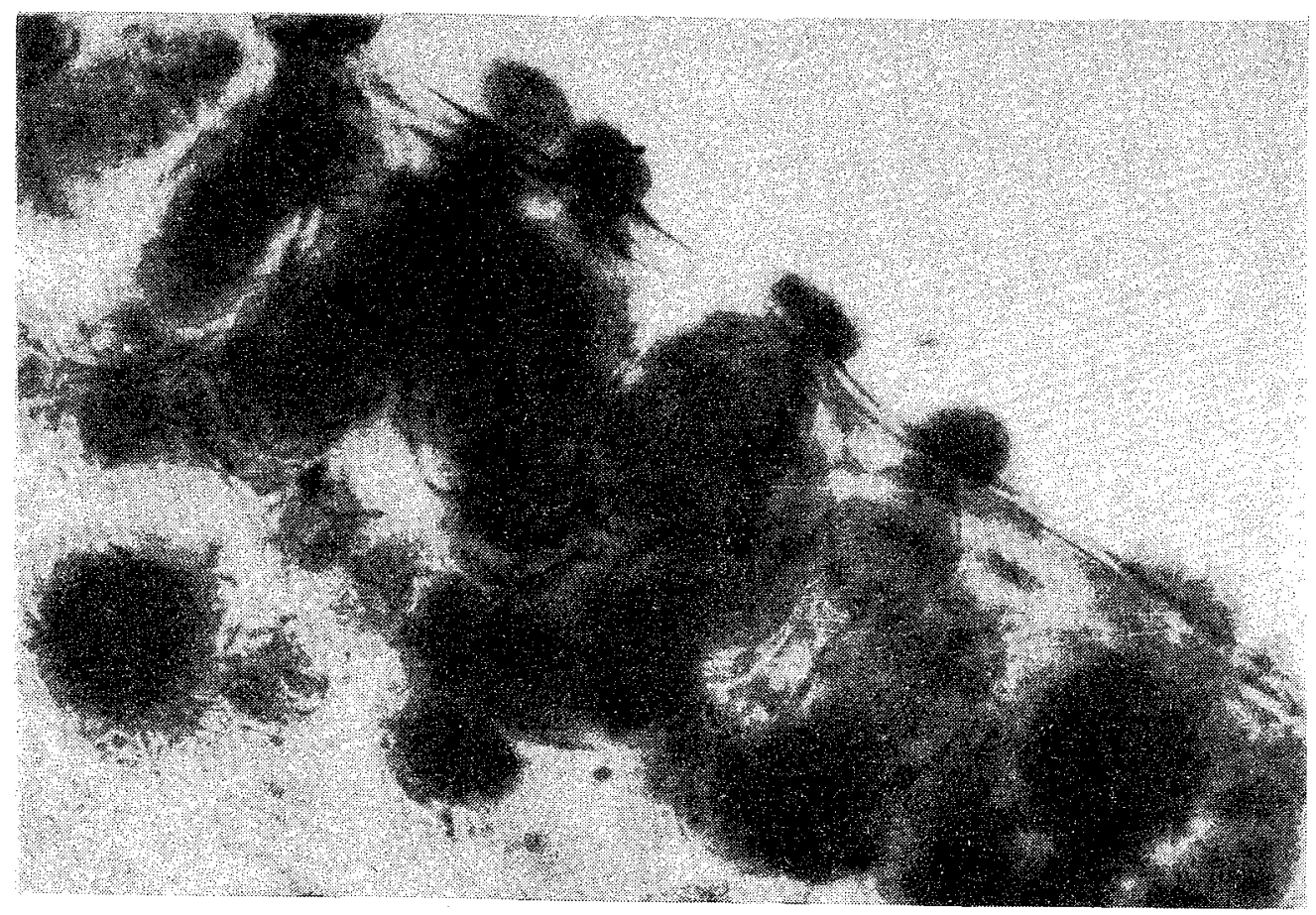

Phot. 3. Longitudinal section through a gill filament. Epithelial layer. Mucous cells at the stage of mucus secretion. Positive reaction for acid mucopolysaccharides (AMPS) in mucous cells. Time of stay in "natural waste water" -1 hour. Sulphate content $-0.77 \mathrm{~g} \mathrm{SO}_{4} / 1$; phosphate content $-0.02 \mathrm{~g} \mathrm{PO}_{4} / 1$, pH 9.7. Toluidine blue. $x 1200$. 


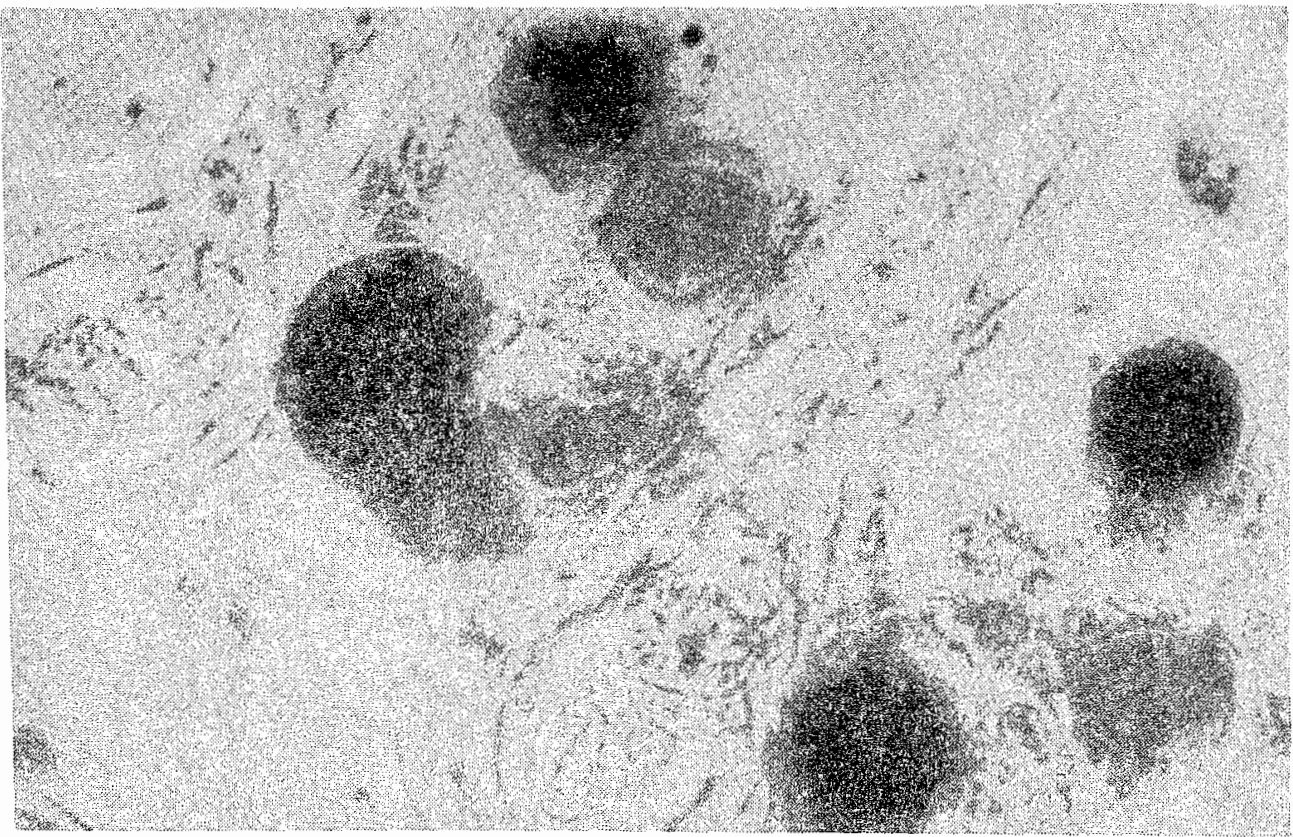

Phot. 4. Mucous cells at the base of gill, lamellae. Some of the cells show a positive reaction for AMPS. The other ones remain unstained after secreting mucus. Time of stay of fishes in "natural waste water" -1 hours. Characteristics of waste water as for Phot. 3. Toluidine blue. $x 1200$.

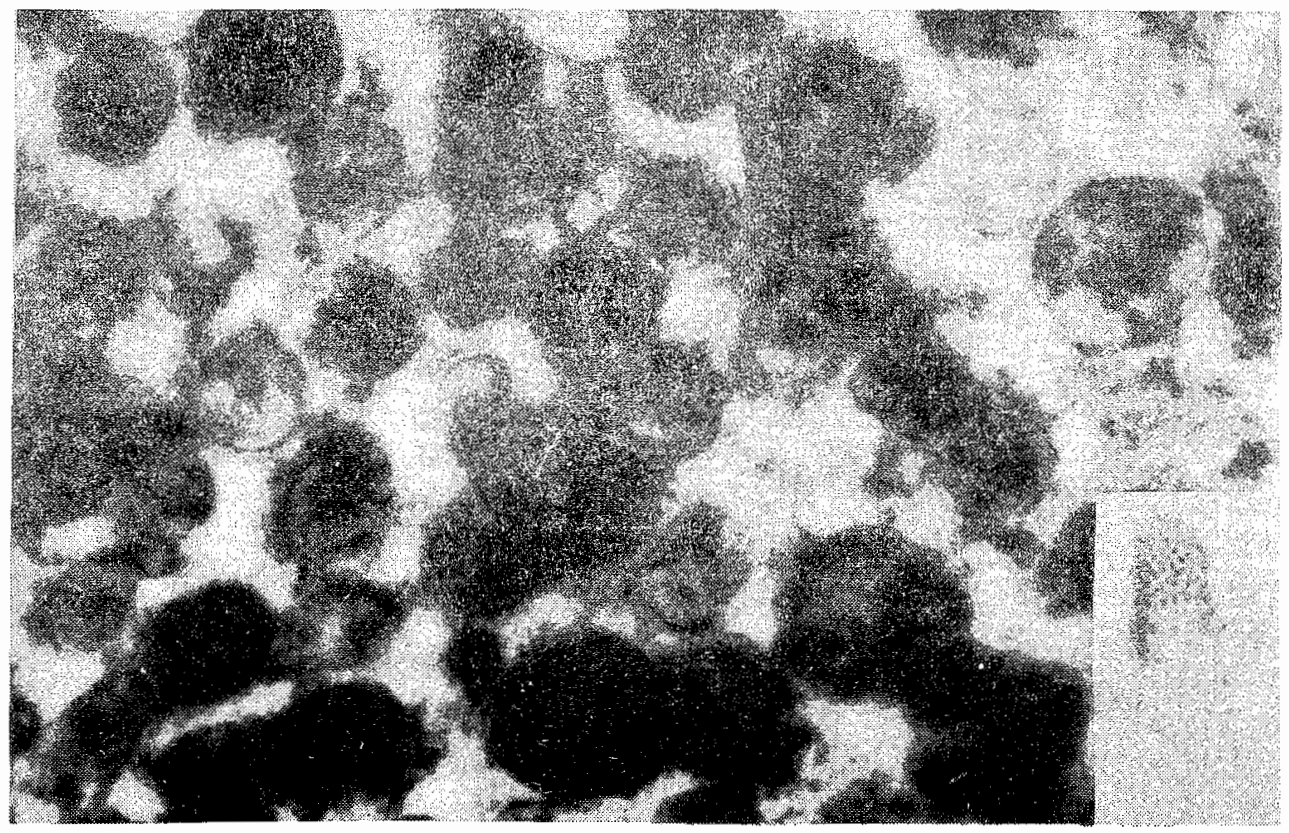

Phot. 5. Mucous cells of top portion of gill filament. In single cells the positive reaction for MPS is decreased, in some cells lacking completely. Time of stay of fishes in "natural waste water" -2 hours.

Characteristics of waste water as for Phot. 3. PAS. x 1200. 


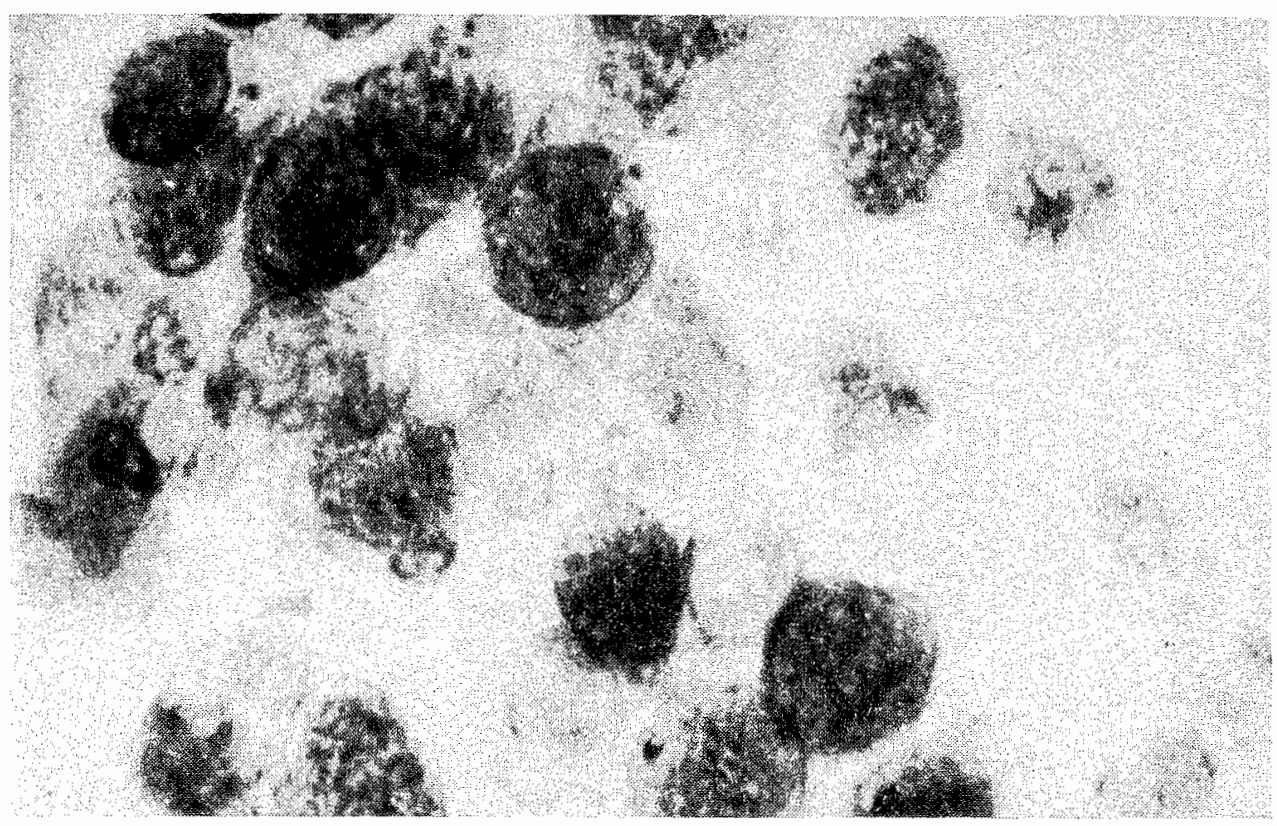

Phot.6. Mucous cells of top portion of gill filament. Lytic changes and breakdown of mucus cells visible. Time of stay of fishes in "Natural waste water" -6 hours. Characteristics of waste water as for Phot. 3. PAS. x 1200.

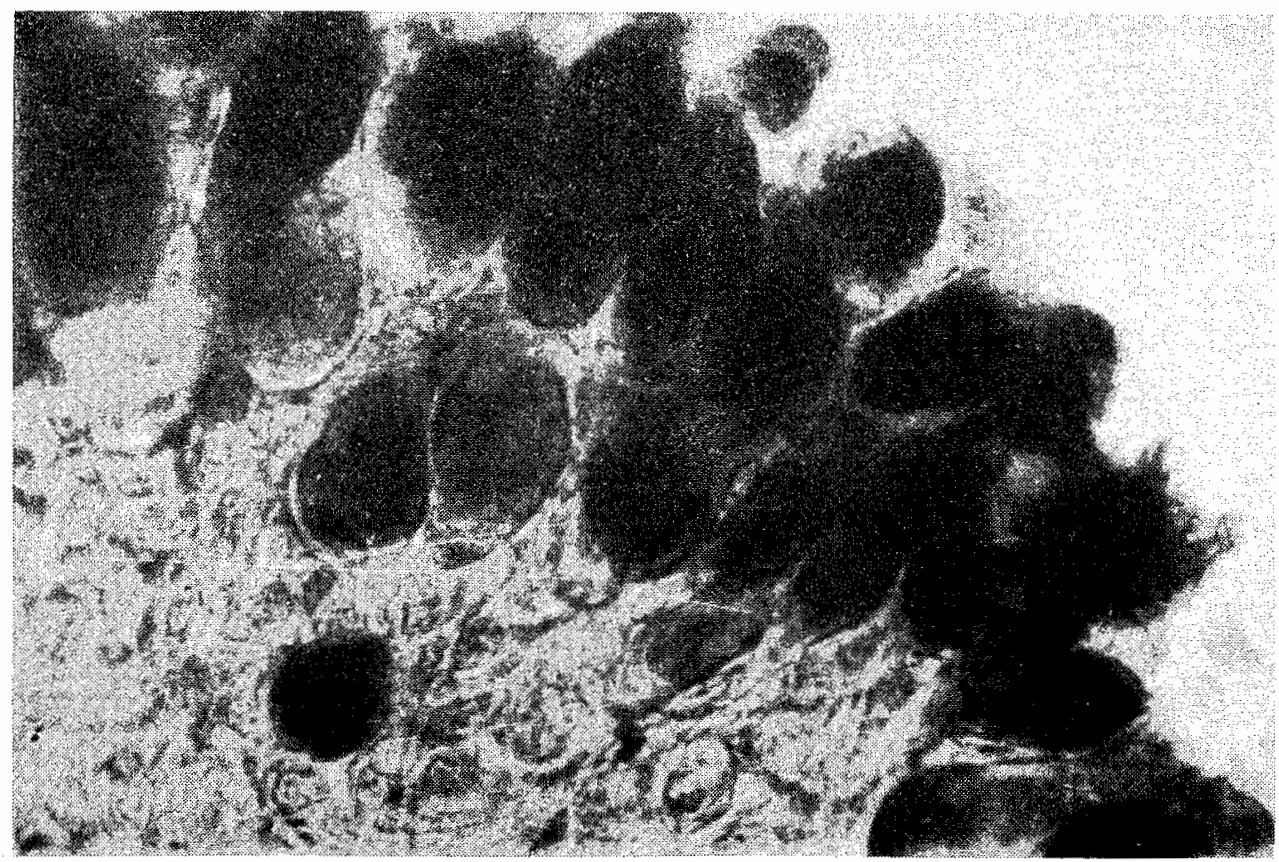

Phot. 7. Control section. Cross-section through a gill filament. Positive reaction for AMPS in mucous cells of epithelial layer. Toluidine blue. $\mathrm{x} 1200$. 


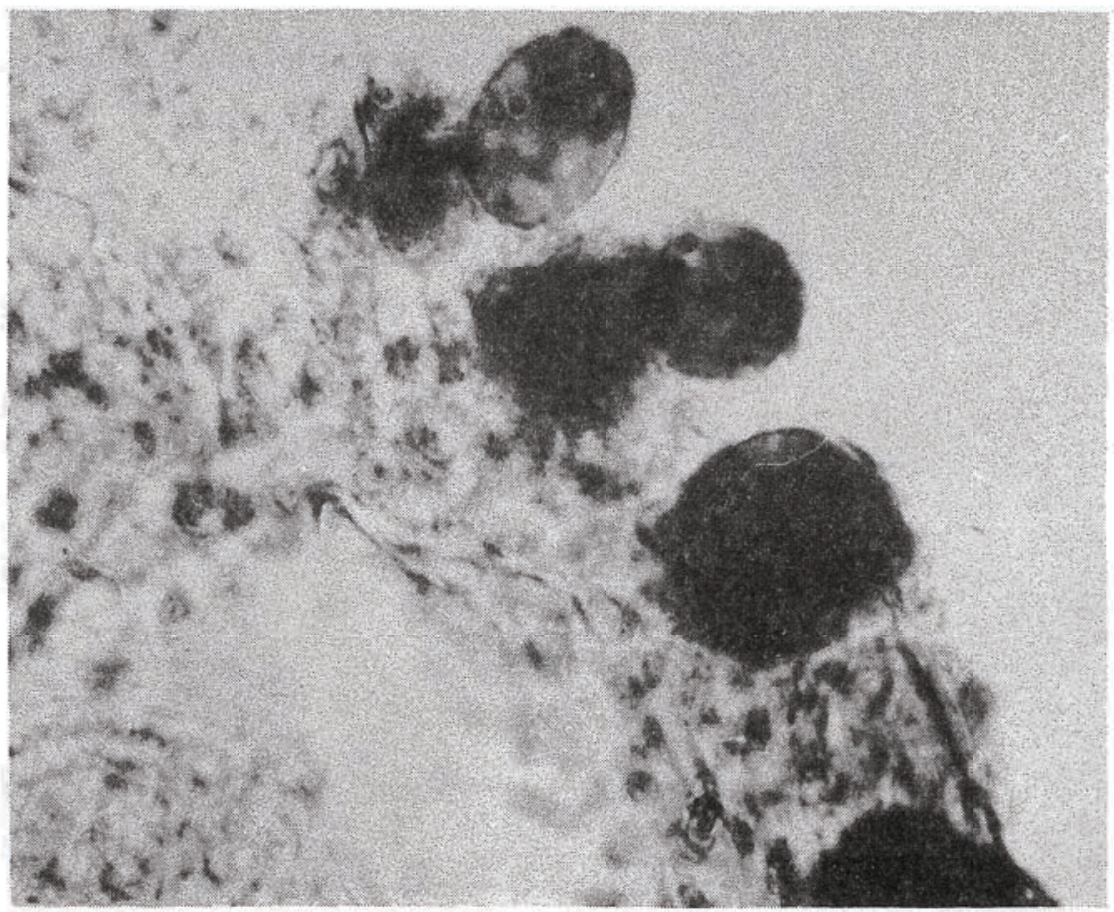

Phot. 8. Cross-section through a gill filament. Infrequent mucous cells with positive reaction for AMPS. Epithelium detached from proper layer. Time of stay of fishes in "natural waste water" - 2 hours. Sulphate content - $1.0 \mathrm{~g} \mathrm{SO}_{4} /$; phosphate content - 0.01 \& PO4/1; pH 9.7. Toluidine blue. $x 1200$.

reaction in infrequent mucous cells, which had undergo a marked delamination and lysis (Phot. 6). A rise in the amount of sulphates in the waste water to $1 \mathrm{~g} \mathrm{SO}_{4} / 1$ at $\mathrm{pH} 9.7$ induced a very rapid fall in the intensity of reaction in PAS - positive substances and staining reactions for AMPS.

Toluidine blue stained only a small number of mucous cells (as compared with the control sections) bordering on the water environment (Phot. 7 and 8). At the same time the continuity of the epithelium was broken and the distance between the epithelium and blood-vessel increased (Phot. 9).

4. Examination of the eel gills in the experimental group exposed to the action of the "artificial waste water"

"Artificial waste water" with a sulphate content of $1 \mathrm{~g} \mathrm{SO} / 1$ and $\mathrm{pH}$ value of 9.0 (Table 2).

In fishes kept under these conditions the PAS positive reaction in the mucus cells was weaker than in the control group. Alcian blue stained the mucous cells blue and the cartilage pale blue. With Astra blue at $\mathrm{pH} 5.5$ the cartilage stained light blue, while the mucous cells bordering on the water environment were stained more intensely. Toluidine blue stained single mucus cells pink to violet.

"Artificial waste water" with a sulphate content of $2.8-3.3 \mathrm{~g} \mathrm{SO}_{4} / 1$ and $\mathrm{pH}$ value of 8-8.5. 


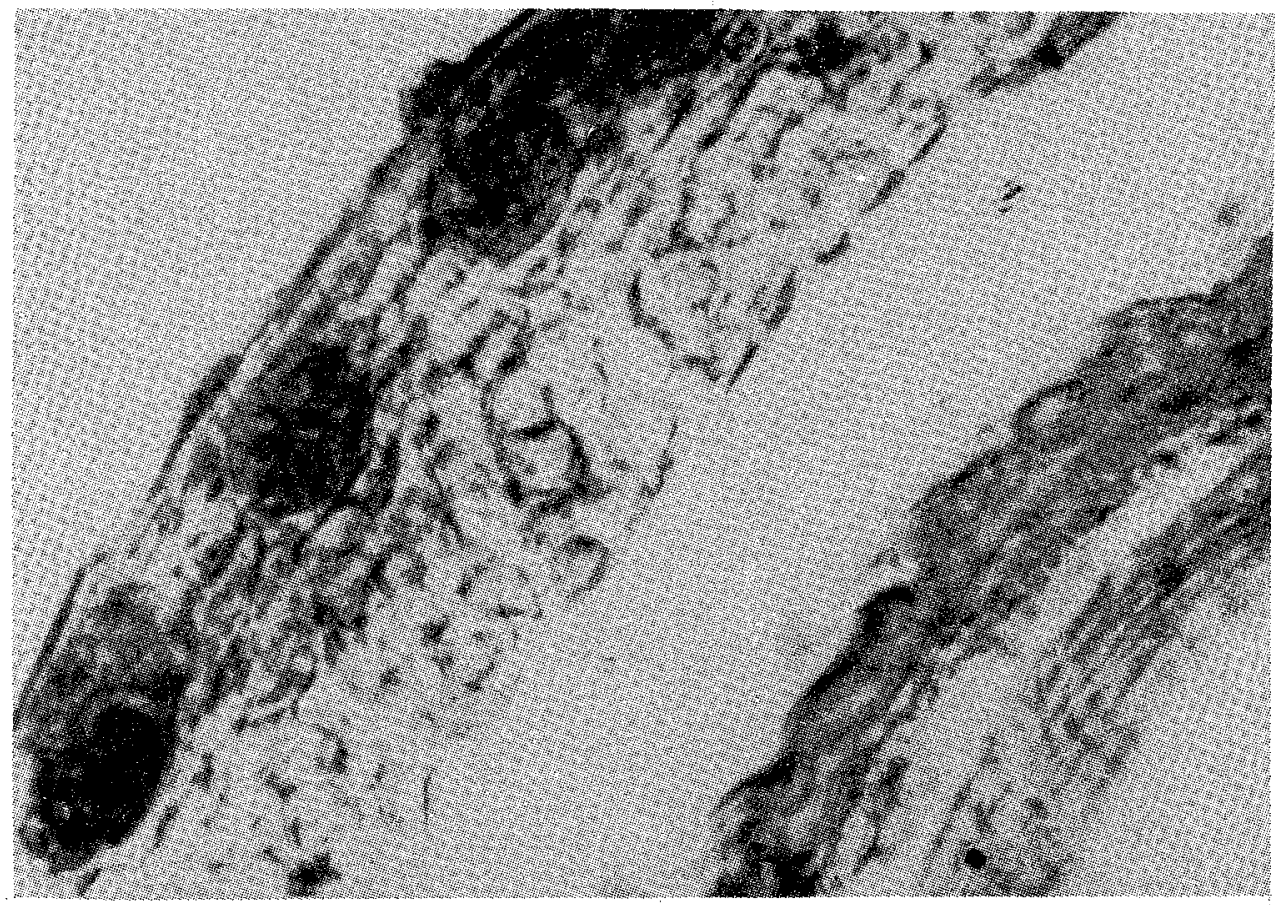

Phot. 9. Cross-section through a gill filament. Detachment of epithelium from proper layer. Slight positive reaction for MPS in single mucous cells. Time of stay of fishes in "natural waste water" - 3 hours. Sulphate content $-1.0 \mathrm{~g} \mathrm{SO}_{4} / 1$; phosphate content $-0.02 \mathrm{~g} \mathrm{PO}_{4} / 1 ; \mathrm{pH} 9.7$. PAS. x 1200 .

In fishes staying in this waste water for 48-72 hours the gill epithelium, especially its mucous cells, showed a PAS positive reaction, which decreased with the time spent by the fishes in this environment. Alcian blue stained the mucous cells of the epithelial tissue weakly and the cartilage was also less intensely stained in comparison with the sections of the control group. Damage to the structure of the respiratory epithelium was noted in fishes kept longer (48 hours) in this environment (Phot. 10). In fishes staying in the "artificial waste water" with the sulphate content raised to 3.6 at pH 11 (Table 2) the reaction for AMPS in the epithelial layer of the gill filaments was weaker. The closer to the margin bordering on the water environment, the less intense staining was observed in the mucous cells (Phot. 11).

"Artificial waste water" with a sulphate content of $4.5 \mathrm{~g} \mathrm{SO}_{4} / 1$ and $\mathrm{pH}$ value of 9.6.

Fishes kept in the waste water with the sulphate content raised to $4.5 \mathrm{~g} \mathrm{SO}_{4} / 1$ and an unchanged phosphate content.showed a slight PAS positive reaction in infrequent mucous cells. The destruction of the cellular structure of the epithelium was often observed (Phot. 12) and there was no reaction in the cartilaginous tissue of the gill filaments (Phot. 13). Toluidine blue also slightly stained some of the mucous cells, the boundaries of which were blurred (Phot. 14). 
Table 2

Biological investigation of eels in "artificial waste water"

\begin{tabular}{|c|c|c|c|c|c|c|c|}
\hline $\begin{array}{l}\text { Aquarium } \\
\text { No }\end{array}$ & $\begin{array}{l}\text { Sulphates } \\
\mathrm{SO}_{4} \\
\mathrm{~g} / 1\end{array}$ & $\begin{array}{l}\text { Phosphates } \\
\mathrm{PO}_{4} \mathrm{P}_{2} \mathrm{O}_{5} \\
\mathrm{~g} / 1\end{array}$ & $\mathrm{pH}$ & $\begin{array}{l}\text { Temp. } \\
\text { in }{ }^{\circ} \mathrm{C}\end{array}$ & $\begin{array}{l}\mathrm{O}_{2} \text { content } \\
\text { in } \mathrm{mg} / \mathrm{l}\end{array}$ & $\begin{array}{l}\text { Time of } \\
\text { stay of } \\
\text { fishes in } \\
\text { waste water, } \\
\text { in hours } \\
\end{array}$ & Symptoms \\
\hline 6 & 1.0 & $0.03 \quad 0.02$ & 9.0 & 14 & 8.0 & 6 & $\begin{aligned} \text { after } 6 \text { hours - no deviation from standard } \\
\text { behaviour }\end{aligned}$ \\
\hline 7 & 1.0 & $0.03 \quad 0.02$ & 11.0 & 13 & 7.5 & 6 & $\begin{array}{l}\text { after } 6 \text { hours - abatement of locomotory } \\
\text { movements }\end{array}$ \\
\hline 8 & 2.0 & $0.02 \quad 0.01$ & 10.7 & 13 & 7.5 & 6 & $\begin{array}{l}\text { after } 6 \text { hours - marked limitation of locomotory } \\
\text { movements }\end{array}$ \\
\hline 9 & 2.8 & $\begin{array}{lll}0.03 & 0.02\end{array}$ & 8.0 & 13 & 8.5 & 72 & $\begin{array}{l}\text { after } 6 \text { hours - marked limitation of locomotory } \\
\text { movements } \\
\text { after } 72 \text { hours - no response to touch }\end{array}$ \\
\hline 10 & 3.3 & $\begin{array}{ll}0.01 & 0.01\end{array}$ & 8.5 & 14 & 7.6 & - & $\begin{array}{l}\text { after } 48 \text { hours- limitation of locomotory move- } \\
\text { ments, no response to touch }\end{array}$ \\
\hline 11 & 3.6 & $0.02 \quad 0.01$ & 11.0 & 13 & 7.0 & 6 & $\begin{aligned} \text { after } 6 \text { hours - disturbances in motory co-ordi- } \\
\text { nation in } 30 \% \text { of fishes examined }\end{aligned}$ \\
\hline 12 & 4.1 & 0.020 .01 & 10.0 & 14 & 8.0 & 3 & $\begin{aligned} \text { after } 1 \text { hour - } & \begin{array}{l}\text { motorial excitation, attempts at } \\
\text { jumping out of aquarium } \\
\text { (symptoms of dy spnoea) }\end{array} \\
\text { after } 2 \text { hours - } & \begin{array}{l}\text { strong tonic convulsions of ske- } \\
\text { letal muscles, bend of trunk, } \\
\text { rigidity of back, loss of body } \\
\text { balance "suspended swimming" }\end{array} \\
\text { after } 3 \text { hours - } & \text { death }\end{aligned}$ \\
\hline 13 & 4.5 & $0.01 \quad 0.01$ & 9.6 & 14 & 8.5 & 2 & 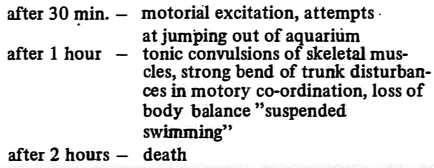 \\
\hline
\end{tabular}




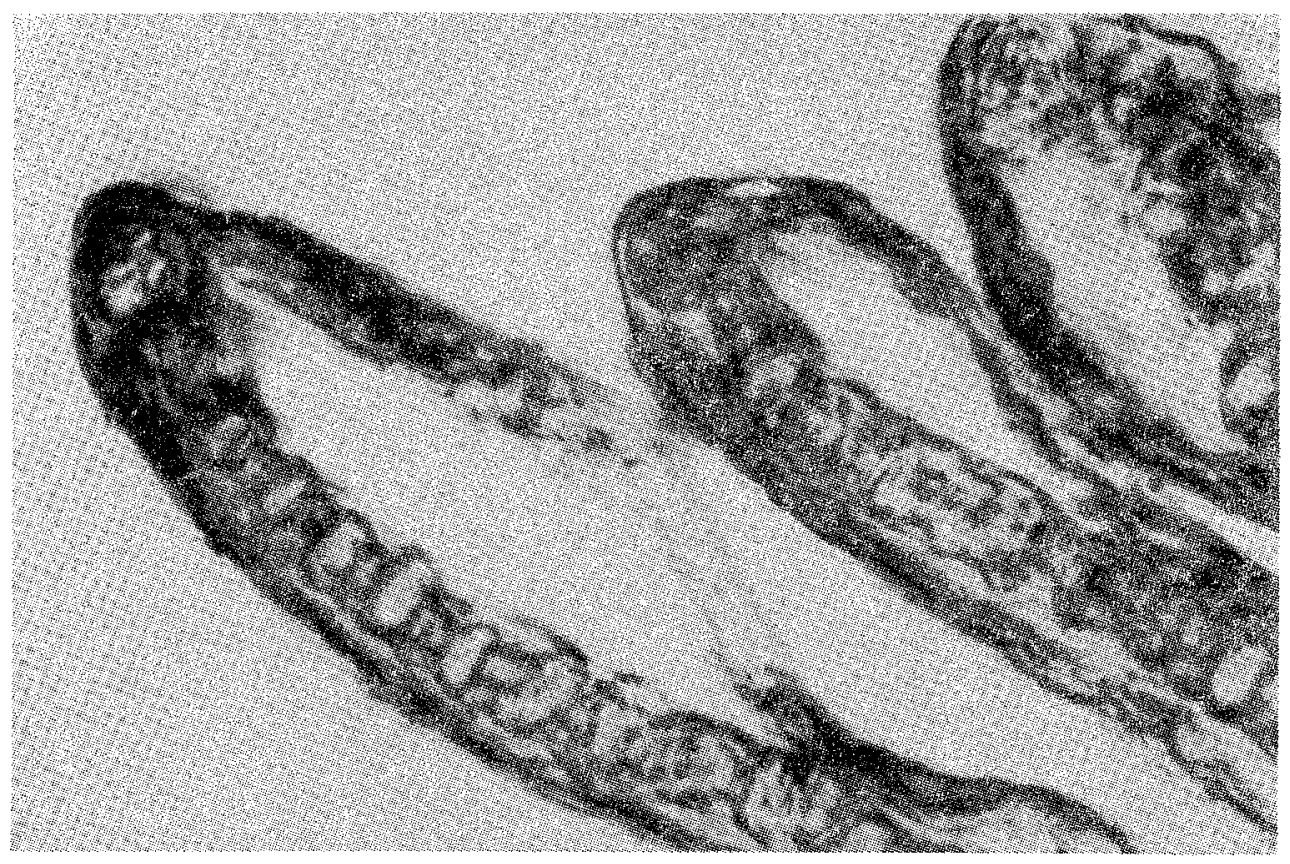

Phot. 10. Longitudinal section through gill lamellae. Damaged structure of respiratory epithelium. Detachment of epithelium from proper layer. Time of stay of fishes in "artificial waste water" -48 hours. Sulphate content $-2.8 \mathrm{~g} \mathrm{SO}_{4} / 1$, phosphate content $-0.03 \mathrm{~g} \mathrm{PO}_{4} / 1, \mathrm{pH}$ 8.0. PAS. x 1200 .

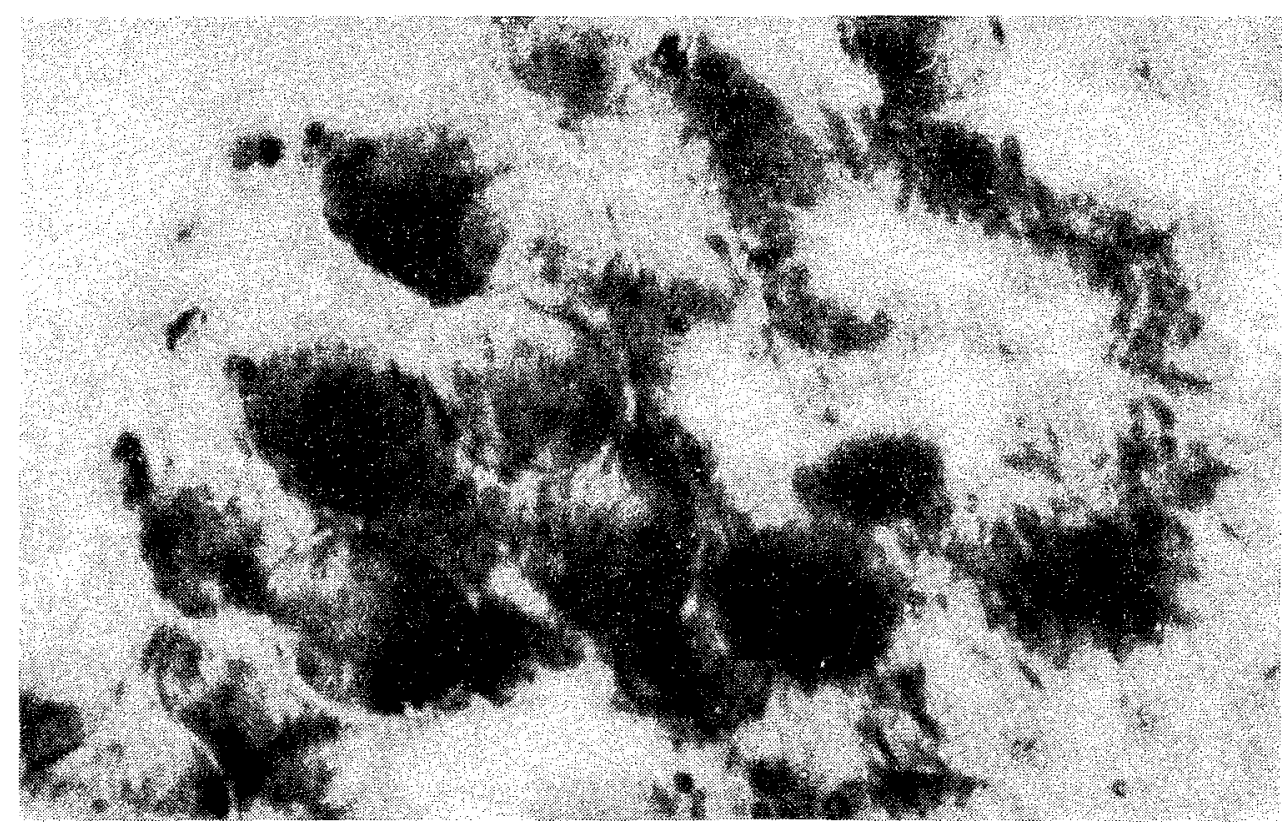

Phot. 11. Cross-section through a gill filament. Epithelial layer. Mucous cells with reduced positive reaction for AMPS. Time of stay of fishes in "artificial waste water" - 6 hours. Sulphate content $3.6 \mathrm{~g} \mathrm{SO}_{4} / 1$; phosphate content $-0.02 \mathrm{~g} \mathrm{PO}_{4} / 1 . \mathrm{pH} 11$. Alcian blue. $\mathrm{x} 1200$. 


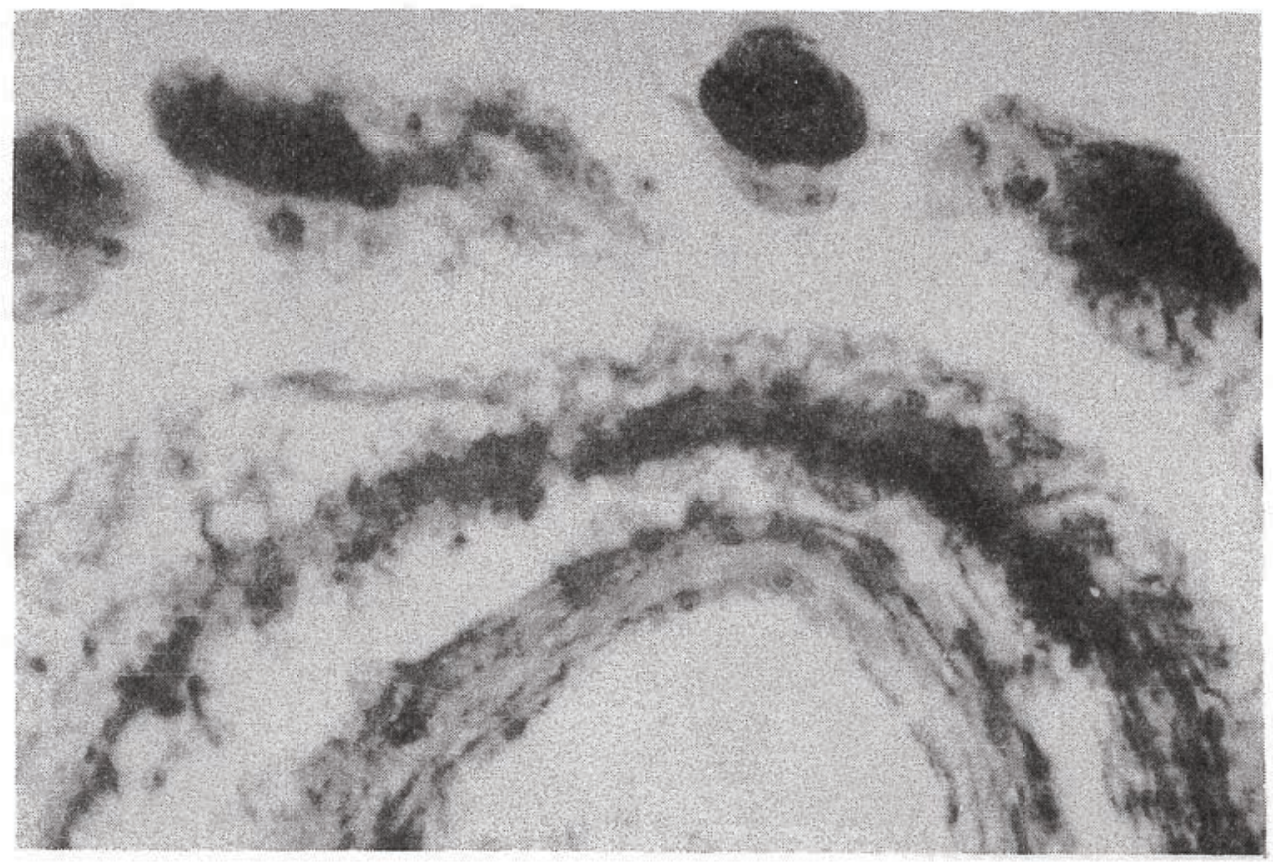

Phot. 12. Cross-section through a gill filament. Damaged structure of epithelium, its continuity broken. Detachment of epithelium from proper layer. Mucous cells very infrequent. Time of stay of fishes in "natural waste water" - 2 hours. Sulphate content $-4.5 \mathrm{~g} \mathrm{SO}_{4} / 1$; phosphate content $-0.01 \mathrm{~g} \mathrm{PO}_{4} / 1, \mathrm{pH}$ 9.6. PAS. x 1200.

A comparison of staining reactions for mucopolysaccharides in the gills of fishes of both the control and experimental groups subjected to the action of the natural and artificial waste water is given in Table 3.

Summing up, it should be emphasized that in both sorts of waste water examined the amount of sulphates and the value of $\mathrm{pH}$ were variable parameters, whereas the phosphate content did not undergo major changes and always ranged between 0.01 and $0.03 \mathrm{~g}$ $\mathrm{PO}_{4} / 1$. In the "artificial waste water" $\mathrm{pH}$ was adjusted, so far as possible in a large mass of water, so that such an environment might be obtained that with similar values of sulphates and equal values of phosphates $\mathrm{pH}$ was a variable factor; this was done to make sure if the high value of $\mathrm{pH}$ was not the only factor responsible for the harmful effects of this environment. In the "artificial waste water" with a sulphate content of $1 \mathrm{~g} \mathrm{SO}_{4} / 1$ at pH 11 fishes still kept alive throughout the period of study (6 hours), whereas in the waste water with a sulphate content of $4.5 \mathrm{~g} \mathrm{SO}_{4} / 1$ at $\mathrm{pH} 9.6$ they died after 2 hours (Table 2). Thus, it should be supposed that high $\mathrm{pH}$ is not the only factor decisive of the harmfulness of waste water containing sulphates and phosphates.

The biological observation of fishes subjected to the action of the "artificial waste water" with a high sulphate content $(4.5 \mathrm{~g})$ showed symptoms of great excitement, 


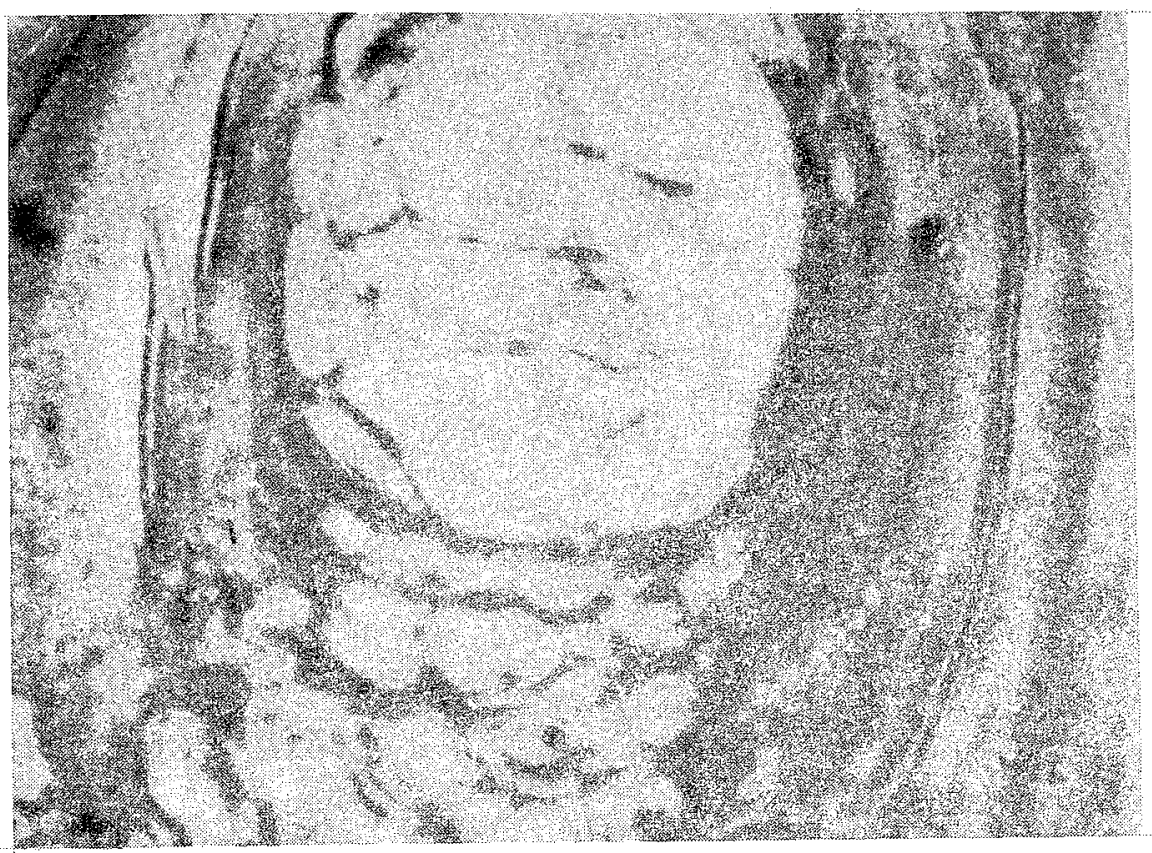

Phot. 13. Cross-section through the cartilaginous chord of a gill filament. Positive reaction for MPS is lacking from the cartilaginous tissue. Time of stay of fishes in "artificial waste water" -2 hours. Characteristics of waste water, as for Phot. 12. PAS. $x 800$.

dyspnoea and disturbances in co-ordination of movements, and the death of the fishes occurred in a relatively short time.

The macroscopic observation of the gills indicated profuse secretion of mucus, especially immediately after the placing of fishes in an environment so unfavourable to them as the waste water was. The large amount of mucus secreted by these fishes, acting as one of the protective measures of the organism and induced probably, among other things, by the irritating action of the waste water, may have caused disturbances in the penetration of oxygen through the gills responsible for dyspnoea.

The changes observed in the intensity of staining reactions for AMPS, taking place in the branchial epithelium of fishes examined in both sorts of waste water, would point to a decrease in the mucopolysaccharides content of the gills of the fishes kept in them for several hours.

Similar changes in the histochemical reactions for acid mucopolysaccharides occurred in the eel gills in both sorts of waste water with an increased sulphate contènt at an alkaline $\mathrm{pH}$. In addition to these histochemical changes, there were some histomorphological changes in the eel gills and also changes in the vital functions of fishes both in the "natural waste water" and artificial waste water".

The rapid changes which occurred in the eel gills and induced a marked decrease in the intensity of staining reactions for AMPS and the damage to the water-blood barrier were 
A comparison of staining reactions for mucopolysaccharides in the gills of eel Anguilla anguilla (L.) 


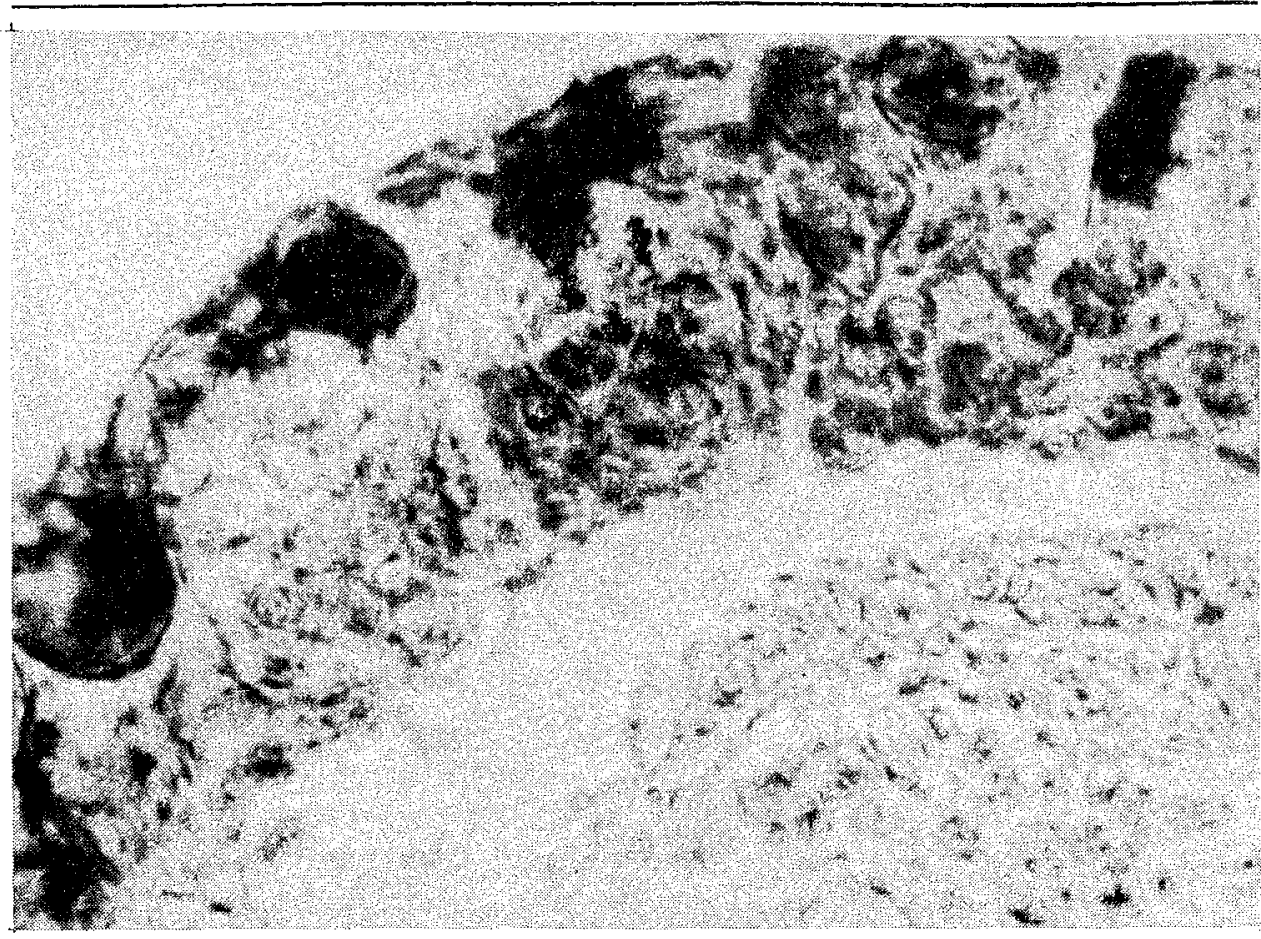

Phot. 14. Cross-section through a gill filament. Damaged structure of epithelium, its continuity broken; epithelium detached from proper layer. Mucous cells very infrequent. Time of stay of fishes in "natural waste water" - 2 hours. Characteristics of waste water, as for Phot. 12. Toluidine blue. x 1200.

observed in the "natural waste water" with a content of $0.77 \mathrm{~g} \mathrm{SO}_{4} / 1$ at $\mathrm{pH} 9.7$, whereas in the "artificial waste water". similar changes took place within an equally short time at a four times as higt sulphate content and a similar $\mathrm{pH}$. This would therefore suggest that in the waste water examined, derived from the Chemical Works there occurs another factor, not included in this study, which has a very harmful effect on eels.

\section{CONCLUSIONS}

1. Industrial wastes containing sulphates and phosphates cause a decrease in the intensity of reactions for mucopolysaccharides (MPS) in the eel gills.

2. The intensity of staining reactions for MPS lowered, as the time of the stay of fishes in the polluted environment was prolonged and also as the amount of sulphates in the environment increased at an alkaline $\mathrm{pH}$, the amount of phosphates in it remaining unchanged.

3. A prolonged stay of fishes (24-72 hours) in the "natural waste water" with a low sulphate content $\left(0.25-0.28 \mathrm{~g} \mathrm{SO}_{4} / 1\right)$ at $\mathrm{pH} 7.7$ brings about a slight decrease in the intensity of reaction for MPS, although no changes have, as yet, occurred in the biological symptoms. 
4. The industrial pollutions, conventionally termed "natural waste water", with a content of $1.0 \mathrm{~g} \mathrm{SO}_{4} / 1$ at $\mathrm{pH} 9.7$, induced a rapid fall in the intensity of staining reactions for MPS. There was often no positive reaction for MPS at all in the mucous cells. Analogous changes were also found in fishes in the "artificial waste water" with a four times as high sulphate content and at a similar $\mathrm{pH}$.

5. Some histomorphological changes, i.e. the blurring of the boundaries of epithelial and connective-tissue cells, the breaking of the continuity of the epithelium, the detachment of the proper layer and the damage to the structure of the respiratory epithelium, were observed along with the histochemical changes (a rapid decrease in the intensity of staining reactions).

6. The histochemical and histomorphological changes in the gills of eels kept in a polluted environment with a markedly increased sulphate content at an alkaline $\mathrm{pH}$ correlate positively with the changes in vital symptoms characteristic of hypoxaemia.

\section{ACKNOWLEDGMENTS}

I owe heartfelt thanks to Prof. dr Remigiusz Wegrzynowicz for aid and valuable remarks given me lavishly during this study.

\section{REFERENCES}

Brimacombe J.S., Webber J.M., 1964: Mucopolysaccharides chemical structure distribution and isolation (B.B.A. Library). American Elsevier Publishing Co: New York 17.

Fujiya M., 1965: Physiological estimation on the effects of pollutants upon aquatic organisms. Advances in Water Pollution Research vol. 3. Pergamon Press. Proceedings of the Second International Conference. Tokyo 1964.

Halsband E., 1972: Etude physiologique du degré de toxicité de différentes substances contenues dans l'eau de mer. - Marine Pollution and Sea Life. Fishing News. Ltd. F.A.O. 1972. London: 233-238.

Heinonen P., Falsk P., 1971: The effect of waste water on fish. Aqua. Fenn. 1, Helsinki: 105-110.

Krygier A., Kasprzak K., 1961: The influence of hydrogen ion concentrations and some other ions on metachromasia in staining mucopolysaccharides with toluidine blue. - Acta Med. Polon. 2, 2: $123-145$.

Kühn O., Koecke H.W., 1956: Histologische und cytologische Veranderungen der Fischkeime nach einwirkung im Wasser enthaltener schädigender Substanzen. Z. für Zellforschung 43: 611-643.

Mc Manus J.K.A., 1946: The demonstration of certain fatty substances in paraffin section. - J. Path. Bact. 5893.

Mowry R.W., 1956: Alcian blue techniques for the histochemical study of acidic carbohydrates. J. Histochem. Cytochem. 4: 406.

Münch O., Ernst B., 1964: Vergleichende Untersuchungen über den histochemischen Mykopolysaccharidnachweis mit der Alzianblau - PAS und der Perjodsäure - Diamin Reaktion. - Acta histochem. 18: 51-57.

Pearse A.G.E., 1968: Histochemistry theoretical and applied 3nd ed. Churchil Ltd. London.

Skidmore J.F, Tovell P.W.A., 1972: Toxic effects of zinc sulphate on the gills of rainbow trout. Water Res. 6, 3: 217-230. 


\section{R. Zbanyszek}

\section{WPŁYW SIARCZANÓW I FOSFORANÓW (ŚCIEKÓW PRZEMYS£OWYCH) NA ZAWARTOŚĆ MUKOPOLISACHARYDÓW .W SKRZELACH WĘGORZA ANGUILLA ANGUILLA (L.)}

\section{Streszczenie}

Przeprowadzono badania wpływu siarczanów i fosforanów zawartych w ściekach przemysłowych Zakładów Chemicznych Police, odprowadzanych do Zalewu Szczecińskiego, na przebieg zmian w zawartości mukopolisacharydów w skrzelach węgorza, z zastosowaniem metod histochemicznych.

Pod wpływem ścieków następował spadek natężénia odczynów barwnych na MPS zarówno w komórkach śluzowych, jak i w chrząstce listków skrzelowych. Stwierdzono ponadto bardzo niekorzystny wpływ "ścieków sztucznych" (z zawartością siarczanów i fosforanów) na organizm ryb, przy stężeniu siarczanów większym od 4,1 $\mathrm{g} \mathrm{SO}_{4} / 1$, w odczynie zasadowym tych ścieków. W ,ściekach naturalnych" odprowadzanych bezpośrednio $\mathrm{z}$ ww. Zakładów, stężenie siarczanów $0,77 \mathrm{~g} \mathrm{SO}_{4} / 1$, (w obecności niewielkiej ilości fosforanów) okazało się bardzo szkodliwe dla węgorzy.

ВЛИЯНИЕ СУЛЬФАТОВ И ФОСФАТОВ ПРОМЫНЛЕННЫХ СТОЧНЫХ ВОД

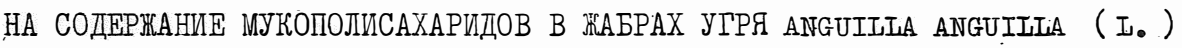

$$
\text { P е } з \text { ю } \mathrm{M} \text { e }
$$

Применяя гистохимические методы исследовали влияние сульфатов и фосфатов, содержащихся в промышленных сточных водах, спускаемых химическим комбинатом "Полице" в Щецинский залив, на ход изменений содержания мукополисахаридов в жабрах угря.

Под влиянием сточных вод наступало снижение интенсивности цветной реакции на мукополисахариды как в слизистых клетках, так и в храще жаберных пластинок. Установлено, кроме того, весьма неблагоприятное влияние "искусственных" сточных вод, содержащих сульфаты и фосфаты, на организм рыбы при концентрации сулјьфатов в щелочной реакции этих сточных вод больше, чем 4,1 г $\mathrm{SO}_{4} /$ л.В "естественных" сточных водах, спускаемых непосредственно из вышеназванного предприятия, концентрация сульфатов 0,77 г $\mathrm{sO}_{4} / \pi$ с наличием небольшого количества фосфатов оказалась очень вредной для угря.

Address:

Dr Regina Zbanyszek Received: 5 VIII 1975-r.

Instytut Ichtiologii AR

71-550 Szczecin, ul. Kazimierza Królewicza 4

Polska - Poland 